Jurnal READ (Research of Empowerment and Development)

http://jos.unsoed.ac.id/index.php/read

e-ISSN : $2745-4746$

Vol. 1 No. 2 Oktober 2020: 77-88

DOI: https://doi.org/10.20884/1.read.2020.1.2.3427

\title{
Towards Community-based Enterprises Empowerment Model for Rural Areas
}

\author{
Zahrotush Sholikhah ${ }^{1}$ \\ 1Department of Management Faculty of Economics Universitas Negeri Yogyakarta \\ E-mail: zahrotush.s@uny.ac.id
}

\begin{abstract}
Entrepreneurship is essential for sustainable social transformation. Entrepreneurial motives and qualities are recognized as central to building every business activity, including small businesses. This study examines various problems faced by the community in its efforts to develop community-based entrepreneurship as an alternative model in rural areas in Indonesia. Data were collected using questionnaires on 83 small business communities located in rural areas in Indonesia. Community-oriented entrepreneurship is an alternative form of social entrepreneurship, pursuing economic benefits based on social networks.
\end{abstract}

Keywords: community-based enterprises, empowerment model, rural development, Indonesia

\begin{abstract}
Abstrak
Kewirausahaan memiliki peran penting untuk transformasi sosial yang berkelanjutan. Motif dan kualitas kewirausahaan diakui sebagai inti dalam membangun setiap aktivitas bisnis, termasuk usaha kecil. Penelitian ini mengkaji berbagai permasalahan yang dihadapi masyarakat dalam upaya mengembangkan kewirausahaan berbasis masyarakat sebagai salah satu model alternatif bisnis di wilayah perdesaan Indonesia. Pengumpulan data dilakukan menggunakan kuesioner pada 83 komunitas usaha kecil yang berada di wilayah kabupaten Banyumas Jawa Tengah. Kewirausahaan yang berorientasi pada masyarakat merupakan salah satu bentuk alternatif dari kewirausahaan sosial yang mengejar keuntungan ekonomi berbasis jaringan sosial.
\end{abstract}

Kata kunci: kewirausahaan berbasis masyarakat, model pemberdayaan, pembangunan pedesaan, Indonesia

\section{Introduction}

The Indonesian government has a plan to be in the ranks of middle-income countries by the year 2025. o achieve it, the government has to employ the right strategy to achieve the vision. A study from Harvard Kennedy School (2014) reports that Indonesia must increase its domestic income growth (real GDP) twofold to achieve its goals.

Regional development based on local potential often places a higher priority on physical development as an indicator of success and still ignores human development. Human development or efforts to improve Human Resources (HR) quality can assist in the development process. According to Sen (in Chalid, 2005), freedom is the core of development, and society must not be strangled. Lack of freedom includes poverty (depriving people of the opportunity to get adequate nutrition), low economic opportunities (such as opportunities for women to work outside the home), and neglect of public facilities. Thus, human development (HR) is the prerequisite of successful regional development (Chalid, 2005).

The formation of quality human resources can increase productivity and maximize economic development. The problem that often arises is that most youngsters are looking for jobs rather than creating jobs (Darwanto, 2012). Today's labor market conditions indicate that the labor supply is greater than the demand, leading to a higher unemployment level. 
Meanwhile, the number of job providers (entrepreneurs) in Indonesia is still small. The economic development of a country depends on its industry growth patterns, which also depends on the competencies of its entrepreneurs (Santhi \& Kumar, 2011).

This theory is in line with the argument made by the economist Joseph Schumpeter in the 1940s regarding the concept of creative destruction, namely as a recurring mechanism and an innovation process in which new production (goods and services) replaces obsolete products. Thus, it is the business sector that plays a significant role in this process. Business firms will be active in productive sectors. Furthermore, Schumpeter argues that the combination of management in the productive sector with the management of resources will increase economic development by creating new entrepreneurs as development accelerators.

As explained earlier, Indonesia aspires to be a middle-income country by 2025 . Achieving this goal is not easy because Indonesia is still having several development problems, such as inequality, poverty, and unemployment. One way to improve community welfare is through regional development by looking at local potential.

Local potential based development in one region allows the area to produce output with comparative advantages (raw materials and market location). With the development of local potential in a region, the regional economy is expected to increase, creating more regional jobs.

\section{Formulation of the problem}

As a developing country, Indonesia faces various economic development problems, especially those related to problems in rural areas. Indonesia's Central Statistics Agency (BPS), in 2010, noted that 49 percent of the population lived in urban areas, while the remaining 51 percent of the population lived in rural areas. The majority of the poor live in the village or suburb area, as shown in Table 1 below:
Table 1. Low Income Population in March 2018 March 2020

\begin{tabular}{lllllll}
\hline & March & Sept. & March & Sept. & March \\
& 2018 & 2018 & 2019 & 2019 & 2020 \\
\hline Urban & 7.02 & 6.89 & 6.69 & 6.56 & 7.38 \\
Rural & 13.20 & 13.10 & 12.85 & 12.60 & 12.82 \\
\hline
\end{tabular}

Source: BPS, 2020

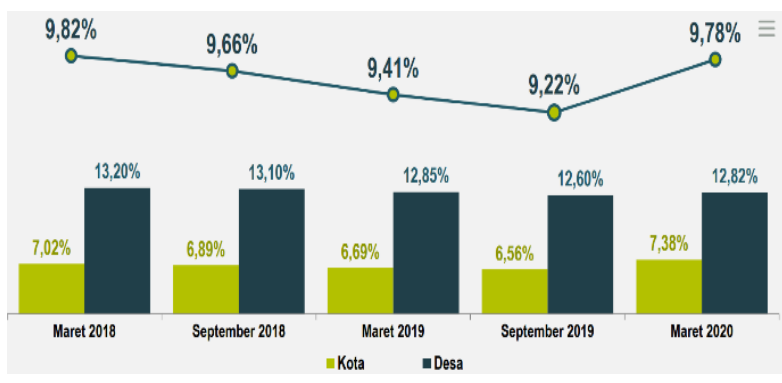

Figure 1. Percentage of poverty in an urban and rural area

The percentage of poor people in urban areas in September 2019 was 6.56 percent and was increased to 7.38 percent in March 2020. Meanwhile, the percentage of poor people in rural areas in September 2019 was 12.60 percent and was increased to 12.82 percent in March 2020. Compared to September 2019, the number of poor people in March 2020 in urban areas increased by 1.3 million people (from 9.86 million people in September 2019 to 11.16 million people in March 2020). Meanwhile, in rural areas, the number increased by 333.9 thousand people (from 14.93 million people in September 2019 to 15.26 million people in March 2020). The Poverty Line in March 2020 was reported to be at IDR 454,652 / capita/ month with the composition of the Food Poverty Line at IDR 335,793 (73.86 percent) and the Non-Food Poverty Line at IDR 118,859 (26.14 percent). On average, in March 2020, Indonesia's poor households were reported to have 4.66 household members. Thus, the average poverty line per poor household is IDR 2,118,678 / poor household/month.

The phenomenon of poverty in urban and rural areas can be explained based on Boeke's economic dualism, which often occurs in developing countries. People living in rural areas use traditional systems (hereditary methods and techniques), 
resulting in lower worker productivity than the modern urban economic system. Furthermore, low productivity indicates the village's low wages, while workers in modern economic systems will have relatively high wages. Also, the skills and abilities they have will further widen the wage difference between the two groups. In the end, it will affect the level of job opportunities and the income gap of the community.

Most of the development problems with poverty and unemployment are relatively higher in the village. Thus, efforts are needed to overcome these development problems to improve people's welfare. The Indonesian government's economic policy is more inclined towards regional development by looking at human and natural resources' local potential.

The availability of labor and business actors in the rural area (village) and raw materials can stimulate economic development through creative destruction mechanisms through community empowerment. Community-based rural entrepreneurs require the ability to create innovative ideas to produce goods and services, which can create jobs. Consideringcreatingat occurred in rural areas; it is necessary to analyze the challenges and opportunities for entrepreneurship in the village.

\section{Literature Review}

The term entrepreneur comes from the French "entrepreneur" and German "Unternehmen," which both mean to run or do business. Meanwhile, in The American Heritage Dictionary, the term entrepreneur is defined as a person who organizes, runs, and calculates risk into a place. Meanwhile, according to Subroto (2013), entrepreneurship is an attitude, enthusiasm, and ability to create something new and useful for oneself and others. Santhi and Kumar, (2011)also argue that the term entrepreneurship is an act of doing business. Someone who is innovating has sharpness in trading and calculating to turn innovation into economic goods.
Martin and Osberg (2007) mention several essential characteristics of entrepreneurs: first, inspiration, an entrepreneur will be inspired to make a change. Second, creativity, the entrepreneur thinks creatively and develops new solutions entirely different from existing ones. Third, direct Action. When an entrepreneur has been inspired and thinks creatively, they will immediately act to manifest the idea rather than waiting for someone else to do it. Fourth, courage; an entrepreneur has the determination to undergo the innovation process, is willing to take risks and failures; the fifth characteristic is fortitude. An entrepreneur has tenacity in producing creative solutions through an understanding of the market.

Meanwhile, according to Oruc et al. (2013), past studies had identified the factors that influence entrepreneurial growth related to rural entrepreneurship. Most of them divide it into two factors, internal factors such as the characteristics of entrepreneurs and business characteristics) and external factors such as population, availability of raw materials, support from the government, characteristics of the labor market and merchandise, quality of the production chain, and financial assistance availability.

Research conducted by Ajibefun and Daramola (2003) in Nigeria found that the business owners' education level strongly influences efficiency and business growth. Educated business owners will significantly impact business sustainability. Therefore, education and training for business actors, especially in rural areas, are essential. Furthermore, knowledge of marketing techniques, distribution, or new technology will also improve business performance.

The influence of infrastructure will have an impact on company performance. The availability of roads, water, electricity, or even an internet network is an essential infrastructure for running a business in rural areas - the better the infrastructure is, the better the performance of business actors in these villages. 
The role of institutions in rural entrepreneurship cannot be ruled out. Oruc et al. (2013)argue that institutions' availability and support influence rural development success.

Expressly, Santhi and Kumar (2011) set out several parameters for the challenges faced by business actors in rural areas, including the family challenge. Business actors, particularly in rural areas, find it difficult to convince their families why they choose to do business instead of working. Second, the social challenge. The business community's evaluation that we prefer relative to other tasks, such as work. Third, the technical challenge. The challenges of technological innovation in the future cannot be seen as straightforward. For example, online shopping makes it easier for customers to buy (physically) without going to the store. Fourthly, there is almost always a financial challenge in running a company. In rural areas, business actors in rural areas usually also use their resources, such as personal investments-finally, the policy task of shaping government policies towards entrepreneurs in rural areas. Most rural enterprises are small and informal. The government should introduce empowerment policies for these small business actors. The problem is that many small and mediumsized enterprises in rural areas are often not registered or still informal, making it difficult for the government to decide on its policies.

\section{Research Methodology}

This study applied the survey method by using both qualitative and quantitative approaches. The survey included 83 rural business actors in the regions of Central Java, West Java, and Yogyakarta. Data collection methods or techniques used in this analysis were observation, questionnaires, interviews, web-based information, and data. To process and interpret the data, we concentrated on factors that become barriers and opportunities of running a company in rural areas. The data analysis is presented based on the results of descriptive and regression analysis. For the regression analysis, referred to Headd (2000) and Oruc et al. (2013), the model can be formulated as follows:

$$
\begin{aligned}
& \mathrm{Yi}=\beta 0+\beta \mathrm{j} \text { ACKDij }+\beta \mathrm{k} \text { ACKBik }+\beta \mathrm{l} \text { ACCSFil } \\
& +\mathrm{ui}
\end{aligned}
$$

$\mathrm{Y}$ is the time-dependent variable to start a company. This variable is a dummy variable, i.e., one means that the business actor did business in 2010-2015, and 0 is the opposite. To see how much new entrepreneurs (new entrances/start-ups) are involved in rural areas' entrepreneurship, the independent variables were divided into three:

KD is a demographic feature, such as gender, age, education level, and migration experience.

$\mathrm{KB}$ is a business attribute, such as the business age, whether it is inherited or not, and the export experience.

CSF is a vital success factor that provides details on criteria that become challenges and a driving force in running an entrepreneurial company. This variable contains perceptual data, so it requires special attention when estimating the above model.

For the ordinal variable estimation technique (CSF), this research refers to the regression method written by Winship and Mare (1984), which treats independent ordinal variables as instrument variables.

\section{Result and Findings}

\section{Internal factors}

Entrepreneur Characteristics

From the survey results, it can be seen that business ownership according to gender (gender) is still From the survey results, it can be seen that business ownership based on gender is still dominated by men, by 61 businesses. However, at the productive age (age 25-40 years), the distribution of business ownership according to gender shows that women's involvement in business fields is more significant than men, 63.64 percent to 44.26 percent. 
Table 2. Business Owners Based on Gender and Age

\begin{tabular}{lll}
\hline Information & $\begin{array}{l}\text { Woman } \\
\text { (person) }\end{array}$ & $\begin{array}{l}\text { Male } \\
\text { (person) }\end{array}$ \\
Age $<25$ years & 2 & 8 \\
Age 25-40 years & 14 & 27 \\
Age $>$ 40 years & 6 & 26 \\
\hline Total & 22 & 61 \\
\hline
\end{tabular}

Meanwhile, according to the level of education, the survey results can be seen in the Graph. This Graph shows that most of the study sample; almost half (57.8 percent) are high school graduates. Even though most village communities have received compulsory education, they prefer to do business, or they may not enter the labor market and prefer to become self-employed.

Business actors who are included in the sample in this study, as previously found, are not only young entrepreneurs who are the majority but also those at the entry-level or new entrepreneurs, as shown in the following table.

Table 3. Length of Business with Year of Start of Business

\begin{tabular}{|c|c|c|c|c|}
\hline \multirow{2}{*}{$\begin{array}{l}\text { Business } \\
\text { Start Year }\end{array}$} & \multicolumn{4}{|c|}{ Length of Business } \\
\hline & $\begin{array}{l}<1 \\
\text { year }\end{array}$ & $\begin{array}{l}1-3 \\
\text { years }\end{array}$ & $\begin{array}{l}>\quad 3 \\
\text { years }\end{array}$ & amount \\
\hline Before 1990 & - & - & 1 & 1 \\
\hline 1990-1995 & - & 1 & 1 & 2 \\
\hline $1995-2000$ & - & - & 10 & 10 \\
\hline $2000-2005$ & - & - & 10 & 10 \\
\hline $2005-2010$ & - & 1 & 22 & 23 \\
\hline $2010-2015$ & 4 & 17 & 16 & 37 \\
\hline amount & 4 & 19 & 60 & 83 \\
\hline
\end{tabular}

Most of the business actors, 60 people in the sample, have been in business for more than three years. However, what is interesting is that the new entrepreneurs who started their business in 2010-2015 dominated the business actors in the villages who were sampled. A total of 37 business actors are included in the new entrepreneur category. Once every five years, the number of rural entrepreneurs has increased, indicating the growing interest of rural residents to get involved in the business.

\section{Business Characteristics}

The survey results show that most of the sample of entrepreneurs in rural areas are in the retail/shop and restaurant type. For Stores / Retail, there were 24 outlets or 28.92 percent, while Restaurants were 21 stalls or 25.3 percent. Meanwhile, those related to agriculture, fishery, and livestock occupy the lowest portion of this business type. Rural areas are facing a limited amount of natural resources as the material for business. Thus, most of these natural products may still be consumed by the community (subsistence), or their production is used for consumption.

There are about 43 business actors whose businesses are production-based. The majority of production-based business actors are household, livestock, and agricultural businesses. Meanwhile, there are 32 businesses whose businesses are re-seller based. The business actors that dominate the re-seller base are retail/store, business owners.

The number of employees and sources of business capital is depicted in table 5 . The majority of business actors in rural areas have less than 20 workers. Likewise, most of the business actors in rural areas are classified as micro and small businesses (micro-businesses employ 1-4 people, while small businesses 5-19 people).

Table 4. Respondents categories based on their business type

\begin{tabular}{lllllllll}
\hline Type & Agriculture & Retail & Fishery & Ranch & Workshop & Restaurant & Others & Total \\
\hline 3 & 24 & 5 & 5 & 5 & 21 & 20 & 83 \\
\hline
\end{tabular}

Table 5. Number of Employees

\begin{tabular}{lllllll}
\hline & \multicolumn{7}{l}{ Number of Employees (person) } & & \\
\cline { 2 - 7 } & $<20$ & $20-40$ & $41-60$ & $61-80$ & $81-100$ & $>100$ \\
\hline Frequency & 78 & 3 & 0 & 1 & 0 & 1 \\
\hline
\end{tabular}


The table shows the survey results on sources of capital in doing business in rural areas. There were 42 respondents from rural business operators who answered that their business capital came from savings, and 21 respondents answered that it came from bank loans.

Table 6. Sources of Business Capital

\begin{tabular}{lllllll}
\hline & \multicolumn{6}{l}{ Sources of Business Capital } \\
\cline { 2 - 7 } & Savings & Family & $\begin{array}{l}\text { Borrow } \\
\text { Friends }\end{array}$ & $\begin{array}{l}\text { Receiving } \\
\text { Payment }\end{array}$ & Borrow Bank & Others \\
\hline Frequency & 42 & 17 & 0 & 2 & 21 & 1 \\
\hline
\end{tabular}

Meanwhile, to see the relationship between the rural business capital source, actors were classified as micro and small entrepreneurs, as shown in the following table:

Table 7. Sources of Business Capital in each Business Group

\begin{tabular}{llllllll}
\hline \multirow{2}{*}{$\begin{array}{l}\text { Number of Workers } \\
\text { (people) }\end{array}$} & \multicolumn{2}{l}{ Sources of Business Capital } \\
\cline { 2 - 7 } & Savings & Family & $\begin{array}{l}\text { Borrow } \\
\text { Friends }\end{array}$ & $\begin{array}{l}\text { Receiving } \\
\text { Payment }\end{array}$ & $\begin{array}{l}\text { Borrow } \\
\text { Bank }\end{array}$ & Others & amount \\
\hline$<20$ & 39 & 16 & 0 & 2 & 20 & 1 & 78 \\
$20-40$ & 2 & - & - & - & 1 & - & 3 \\
$41-60$ & - & - & - & - & - & - & 0 \\
$61-80$ & - & 1 & - & - & - & - & 1 \\
$81-100$ & - & - & - & - & - & - & 0 \\
$>100$ & 1 & - & - & - & - & - & 1 \\
\hline amount & 42 & 17 & 0 & 2 & 21 & 1 & 83 \\
\hline
\end{tabular}

The table above shows that the capital sources for micro and small enterprises in rural areas are diverse. Most of the capital comes from micro and small businesses in the village from savings, followed by bank loans and family loans.

The composition of the company's assets can be seen in the table below:

Table 8. Asset Composition

\begin{tabular}{|c|c|c|c|c|c|c|c|}
\hline \multirow{2}{*}{ Number of Workers (people) } & \multicolumn{7}{|c|}{ Asset Source } \\
\hline & Alone & Leasing & Borrow & Grant & Legacy & Others & amount \\
\hline$<20$ & 63 & 4 & 6 & 0 & 5 & - & 78 \\
\hline $20-40$ & 3 & - & - & - & - & - & 3 \\
\hline $41-60$ & - & - & - & - & - & - & 0 \\
\hline $61-80$ & 1 & - & - & - & - & - & 1 \\
\hline $81-100$ & - & - & - & - & - & - & 0 \\
\hline$>100$ & 1 & - & - & - & - & - & 1 \\
\hline amount & 68 & 4 & 6 & 0 & 5 & - & 83 \\
\hline
\end{tabular}

Most of the company's assets are obtained from the personal assets of the company owners. Meanwhile, related to the business criteria, the Source of assets for micro and small businesses comes from the owner's savings (63 micro and small business actors).

\section{External Factors}

Apart from being influenced by internal factors, business characteristics and rural entrepreneurship are also influenced by external factors. Among these external factors are: 


\section{Accessibility}

This aspect is related to the access of business actors in rural areas to roads, the internet, clean water, and electricity. The survey results show that the obstacle for business actors in rural areas is internet access. Most internet facilities are located in cities and often do not reach rural areas or even remote areas. This limited internet access can be an obstacle, especially in the current era, where competition for marketing products, both goods, and services, is online.

\section{Distance}

Furthermore, distance can also affect entrepreneurial interest in rural areas. Entrepreneurs can choose a cheaper business location, whether closer to the Source of production factors (raw materials and labor) or closer to the market. As the following survey results show, most business actors are located by considering the market aspect. It can be understood that most respondents have businesses that are engaged in shops/retail and restaurants, so they tend to prefer business locations close to the market. Meanwhile, the distance from government institutions shows that; the distance to public services in such as government institutions is perceived by the respondents to be not close enough. Most government institutions are located in the cities, and some respondents are located in villages. The respondents feel that financial services (banks or non-bank financial institutions) can be reached easily. Most of the buyers of products from business actors are for personal consumption (Graph). It is obtained that 63.86 percent of respondents whose goods they sell are used for consumer consumption. This finding is consistent with previous business actors' characteristics, mostly in the business sector for consumption. Meanwhile, 13.25 percent of the goods sold for resale or consumers were the re-sellers.

For the migration experience, 29 respondents were local people or had never migrated; the rest were mostly immigrants, as many as 54 respondents. To find out the survey results regarding the supporting and inhibiting factors for entrepreneurs in rural areas to run a business. This study uses a Likert Summated Rating (LSR). LSR can show the tendency of respondents' perceptions of the statements submitted.

Using LSR, we can find out the obstacles in running an entrepreneurial business in rural areas.

The results of LSR data processing shows that most respondents agree with the ease of administration aspect. Alternatively, when running their business, entrepreneurs in rural areas consider administration to be an essential aspect.

\section{Administrative Aspects}

Table 9. Results of LSR for Administrative Aspects

\begin{tabular}{|c|c|c|c|c|c|}
\hline \multicolumn{6}{|l|}{ Question Type: Positive Question } \\
\hline \multicolumn{3}{|l|}{ Total Score For Each Respondent } & \multicolumn{3}{|c|}{ Total Score For All Respondents } \\
\hline Maximum & $5 \times 3$ items & 15 & Maximum & $83 \times 15$ & 1245 \\
\hline Minimum & $1 \times 3$ item & 3 & Minimum & $83 \times 3$ & 249 \\
\hline Median & 3x3item & 9 & Median & $83 \times 9$ & 747 \\
\hline Quartile I & $2 \times 3$ items & 6 & Quartile I & $83 \times 6$ & 498 \\
\hline Quartile II & $4 \times 3$ items & 12 & Quartile II & $83 \times 12$ & 996 \\
\hline Acquisition Rate & 843 & & & & \\
\hline Conclusion & Agree & & & & \\
\hline
\end{tabular}


Infrastructure

Table 10. Results of LSR for Administrative Aspects

\begin{tabular}{llllll}
\hline Question Type: Positive Question & \multicolumn{5}{c}{ Total Score For All Respondents } \\
\hline Total Score For Each Respondent & & \multicolumn{5}{c}{ Maximum } & $83 \times 15$ & 1245 \\
\hline Maximum & $5 \times 3$ items & 15 & At a minimum & $83 \times 3$ & 249 \\
At a minimum & $1 \times 3$ item & 3 & Median & $83 \times 9$ & 747 \\
Median & $3 \times 3$ item & 9 & $63 \times 6$ & 498 \\
Quartile I & $2 \times 3$ items & 6 & Quartile I & $83 \times 12$ & 996 \\
Quartile II & $4 \times 3$ items & 12 & Quartile II & $83 \times 12$ & \\
\hline Result Score & 951 & & & & \\
Conclusion & Agree & & & & \\
\hline
\end{tabular}

For the infrastructure aspect, the results show that most of the respondents agreed. When running their business, respondents want adequate infrastructures such as low transportation costs, road access, and the existence of public transportation. Furthermore, the absence of these facilities can become an obstacle for them in running a business.

\section{Ability}

Table 11. Results of LSR for Administrative Aspects

\begin{tabular}{llllll}
\hline Question Type: Positive Question & & & & \\
\hline Total Score For Each Respondent & $5 \times 4$ items & 20 & Maximum & $83 \times 20$ & 1660 \\
\hline Maximum & $1 \times 4$ item & 4 & At a minimum & $83 \times 4$ & 332 \\
At a minimum & $3 \times 4$ items & 12 & Median & $83 \times 12$ & 996 \\
Median & $2 \times 4$ items & 8 & Quartile I & $83 \times 8$ & 664 \\
Quartile I & $4 \times 4$ items & 16 & Quartile II & $83 \times 16$ & 1328 \\
Quartile II & 1323 & & & \\
\hline Result Score & Agree & & & \\
Conclusion & & &
\end{tabular}

From the aspect of business capability, the results of the LSR analysis show that most respondents agreed. It means that they consider the business's ability to be an important factor, such as having a skilled workforce.

\section{Marketing Aspects}

Table 12. Results of LSR for Administrative Aspects

\begin{tabular}{lllllll}
\hline Question Type: Positive Question & & & & \\
\hline Total Score For Each Respondent & & & \multicolumn{4}{c}{ Total Score For All Respondents } \\
\hline Maximum & $5 \times 6$ items & 30 & Maximum & $83 \times 30$ & 2490 \\
At a minimum & $1 \times 6$ items & 6 & At a minimum & $83 \times 6$ & 498 \\
Median & $3 \times 6$ items & 18 & Median & $83 \times 18$ & 1494 \\
Quartile I & $2 \times 6$ items & 12 & Quartile I & $83 \times 12$ & 996 \\
Quartile II & $4 \times 6$ items & 24 & Quartile II & $83 \times 24$ & 1992 \\
\hline Result Score & 1690 & & & & \\
Conclusion & Agree & & & & \\
\hline
\end{tabular}


Meanwhile, for the marketing aspect, the LSR value shows the number 1690. Thus the respondents mostly agree with the statement related to the marketing aspect. Respondents view marketing aspects such as ease of executing marketing activities, few competitors, cheap and easy to obtain raw materials, and proximity to the market that will influence them in running their business.

\section{Performance}

Table 13. Results of LSR for Administrative Aspects

\begin{tabular}{llllll}
\hline Question Type: Positive Question & & & \\
\hline Total Score For Each Respondent & & & Total Score For All Respondents \\
Maximum & $5 \times 3$ items & 15 & Maximum & $83 \times 15$ & 1245 \\
At a minimum & $1 \times 3$ item & 3 & At a minimum & $83 \times 3$ & 249 \\
Median & $3 \times 3 i t e m$ & 9 & Median & $83 \times 9$ & 747 \\
Quartile I & $2 \times 3$ items & 6 & Quartile I & $83 \times 6$ & 498 \\
Quartile II & $4 \times 3$ items & 12 & Quartile II & $83 \times 12$ & 996 \\
\hline Result Score & 918 & & & & \\
Conclusion & Agree & & & & \\
\hline
\end{tabular}

For the performance aspect, the results of the LSR show that most respondents consider performance a vital aspect of running their business.

\section{Financial}

Table 14. Results of LSR for Administrative Aspects

\begin{tabular}{|c|c|c|c|c|c|}
\hline \multicolumn{6}{|l|}{ Question Type: Positive Question } \\
\hline \multicolumn{3}{|l|}{ Total Score For Each Respondent } & \multicolumn{3}{|c|}{ Total Score For All Respondents } \\
\hline Maximum & $5 \times 2$ items & 10 & Maximum & $83 X 10$ & 830 \\
\hline At a minimum & $1 \times 2$ item & 2 & At a minimum & $83 \times 2$ & 166 \\
\hline Median & $3 \times 2$ items & 6 & Median & $83 \times 6$ & 498 \\
\hline Quartile I & $2 \times 2$ items & 4 & Quartile I & $83 \times 4$ & 332 \\
\hline Quartile II & $4 \times 2$ items & 8 & Quartile II & $83 \times 8$ & 664 \\
\hline Result Score & 608 & & & & \\
\hline Conclusion & Agree & & & & \\
\hline
\end{tabular}

Meanwhile, for the financial aspect, the results of the LSR show that most respondents agree that financial criteria (such as the ease of obtaining a loan and large business profits) are factors that influence running a business. It means that if these financial factors are inadequate, such as difficulty obtaining credit and low business profits, it will become an obstacle for entrepreneurs in rural areas to run a business.
Drivers of Business Success

Respondents were asked about the contributing factors and the constraints of their business success. Unlike the previous method, the analysis of the driving factors for success uses Likert analysis in each item using the Likert index. From the calculation of the Likert index, the following results are obtained: 
Table 15. Likert Index Calculation Results

\begin{tabular}{llll}
\hline No. & Criteria & index & Result \\
\hline 1 & Support from Family & 89.15662651 & SP \\
2 & Availability of Production Materials & 88.75502008 & SP \\
3 & Good employee & 88.75502008 & SP \\
4 & Relationships with Other Partners & 83.93574297 & SP \\
5 & Business Network & 81.52610442 & SP \\
6 & Government Support & 79.11646586 & SP \\
7 & Receiving Loans & 73.89558233 & SP \\
8 & Business owner training & 71.48594378 & SP \\
9 & Overseas education & 41.36546185 & P \\
\hline Description: P is significant SP is critical & &
\end{tabular}

Of all the factors driving the success in running a business, it can be seen from the index table above that the most important thing is family support (index value 89.1). The lowest index value is education abroad, with a value of 41.36, even though the respondents still consider it an essential factor in running their business.

Regression Results

Table 16. Regression Results

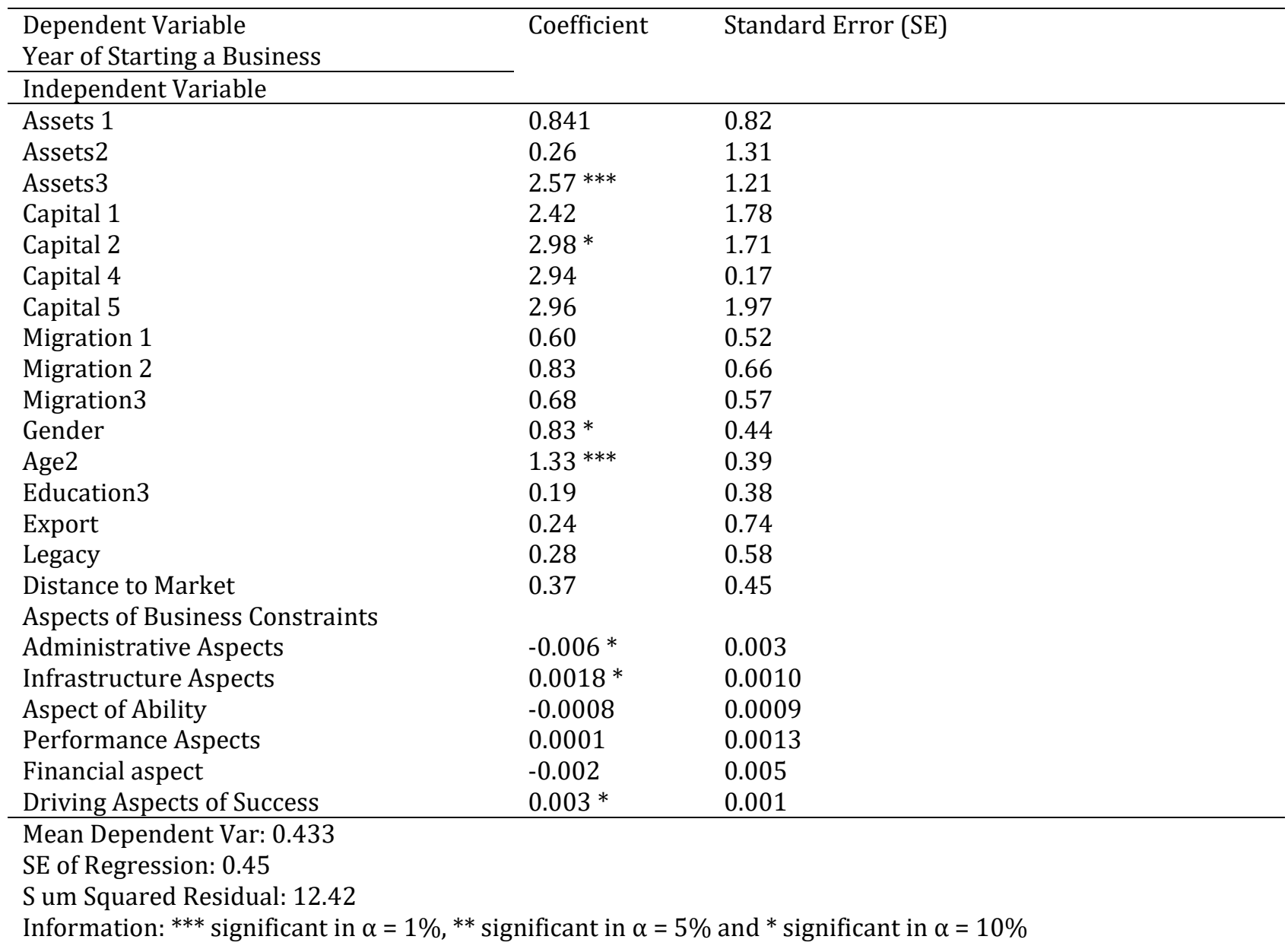

The findings of the Probit regression from an internal point of view or show that several factors stimulate nascent demographic characteristics: age and gender entrepreneurs to start their businesses. First, variables. Entrepreneurs between 25 and 40 
are more likely to become entrepreneurs in the last five years. This result is consistent with the respondents' demographic conditions, most of whom are young entrepreneurs who have just started their business. In other words, young people in rural areas are more likely to become entrepreneurs in rural areas. In the meantime, from a gender viewpoint, it reveals that men are more likely to be selfemployed than women in the last five years.

There are two enabling factors that form market characteristics perspectives: sources of funding and capital sources. The Source of asset funding that dramatically influenced starting a company over the last five years was funding from loans. In other words, most young entrepreneurs funded their assets through loans. The capital aspect that significantly affects the probability of starting a company is the capital that comes from the family. As is usually the case, family money is not that big, and sometimes new entrepreneurs pursue other sources of funding, such as bank loans.

Market constraints include organizational and technological factors. Meanwhile, the administrative aspect is the aspect of the constraints of the industry. Regression results show a negative relationship between business constraints and the likelihood of starting a business in the last five years. More administrative constraints will increase the possibility of starting a business. This finding is not common, or it could be that the business actors who have started their business in the

\section{References}

Ajibefun, I. A., \& Daramola, A. G. (2003). Determinants of technical and allocative efficiency of micro-enterprises: firmlevel evidence from Nigeria. African Development Review, 15(2-3), 353-395.

Chalid, P. (2005). Otonomi daerah: masalah, pemberdayaan, dan konflik. Kemitraan.

$\begin{array}{ccr}\text { Darwanto, D. } & \text { (2012). } & \begin{array}{r}\text { Peran } \\ \text { Entrepreneurship } \\ \text { Dalam }\end{array}\end{array}$ last five years have not thought about administrative problems. In the case of infrastructure constraints, the regression results suggest a positive relationship. The more limited the infrastructure factor would reduce the chances of becoming an entrepreneur over the last five years.

From the ease of business: variable aspects of driving success. Meanwhile, the performance driver indicator indicates a favorable association with the possibility that people will become entrepreneurs in the last five years. As a result, the higher the driving aspects (such as family support, availability of labor, and raw materials), the more likely it will be for a business actor to start a business.

\section{Conclusion}

From the results obtained, the following conclusions can be drawn: first, four factors affect a person's willingness to enter the business world, including demographic characteristics, business characteristics, business constraints, and some factors that make it possible to succeed. Second, age and sex (gender) is the most influential demographic factors, while the most influential market aspect is the source of capital and the funding of properties. Besides, management and infrastructure dimensions are the most prominent obstacles. The aspects of the supporting factors' success impact increasing the possibility of a new company being established.

Pertumbuhan Ekonomi Dan Peningkatan Kesejahteraan Masyarakat. Prosiding Riset Terapan Bldang Manalemen \& Bisnls NNGKAT N4SIONAL JUIWSW Adminlstrasl Bisnls Politeknik Negerl SEMARANG 2012, 11-24.

Headd, B. (2000). The characteristics of small-business employees. Monthly Lab. Rev., 123, 13.

Martin, R. L., \& Osberg, S. (2007). Social 
entrepreneurship: The case for definition. Stanford social innovation review Stanford.

Oruc, N., Delalic, S., Kamenjas-CEDAR, L., Narazani, E., Mara, I., \& Saka-ACSER, T. (2013). Linking rural entrepreneurs and diaspora in Albania and BosniaHerzegovina. Regional Research Promotion Program Western Balkan, 1124.

Santhi, N., \& Kumar, S. R. (2011). Entrepreneurship challenges and opportunities in India. Bonfring International Journal of Industrial Engineering and Management Science, 1 (Special Issue Inaugural Special Issue),
$14-16$.

Saragih, J. R. (2015). Perencanaan wilayah dan pengembangan ekonomi lokal berbasis pertanian: teori dan aplikasi. Pustaka Pelajar.

Subroto, W. T. (2013). Entrepreneurship development course to foster character merchandise in support economic growth. Asian Economic and Financial Review, 3(6), 762.

Winship, C., \& Mare, R. D. (1984). Regression models with ordinal variables. American Sociological Review, 512-525. 